\title{
Bidirectional Transfer in Korea-Chinese Children's Language Acquisition
}

\author{
Zhenyi Shao \\ College of Humanities, Tiangong University, Tianjin, China \\ Email: zhenyishao2019@163.com
}

How to cite this paper: Shao, Z.Y. (2020) Bidirectional Transfer in Korea-Chinese Children's Language Acquisition. Open Access Library Journal, 7: e6243.

https://doi.org/10.4236/oalib.1106243

Received: March 18, 2020

Accepted: April 13, 2020

Published: April 16, 2020

Copyright $\odot 2020$ by author(s) and Open Access Library Inc.

This work is licensed under the Creative Commons Attribution International License (CC BY 4.0).

http://creativecommons.org/licenses/by/4.0/

\section{(c) (i) Open Access}

\begin{abstract}
With the development of economy, international trade and commerce frequently boomed, multicultural families are gradually increasing, so developing children's bilingual competence has become a focused issue. This thesis collects 38 Korean-Chinese children's bilingual proficiency test paper to research language bidirectional transfer in the process of $\mathrm{K}-\mathrm{C}$ children bilingual acquisition. There are two types of children involved, that one is bilingual children who born in china, with a Korean parent and a Chinese parent; the other type is early second acquisition children who came to China before the age of three, and their parents are both Korean. Early second acquisition children have lived in a Chinese environment since childhood. Based on the influence of bilingual language community and early childhood education intervention, they input Chinese signals implicitly, and started to learn Chinese systematically in kindergarten at around age of three. Two types of children are affected by language transfer from Korean and Chinese. As far as the pronunciation is concerned, $\mathrm{K}-\mathrm{C}$ children have difficulty in identifying Pinyin, recognition of tone labeling, and pronunciation of speech cross languages; in terms of syntax, K-C children show object-verb inversion and shift of topic focus of prepositional verb. This thesis mainly involves error analysis of speech and syntactic structure, classification of error item, to study the cross-lingual impact between Chinese-Korean in children's bilingual acquisition who are under the Chinese environment, which will help to build dynamic schema of bidirectional transfer in K-C children language acquisition, and final finally give some suggestions.
\end{abstract}

\section{Subject Areas}

Linguistics, Language Acquisition

\section{Keywords}

Bidirectional Transfer, Language Acquisition, Korean-Chinese Children, 


\section{Introduction}

With the strengthening of globalization, economic cooperation and cultural communication among different region and nation have been getting gradually deeper. As one of the largest port cities in northern China, Tianjin is close to the Bohai Sea and is an important port for import and export trade in Promoting Beijing-Tianjin-Hebei Collaborative Development. Meanwhile, geographically, Tianjin is adjacent to the Korean Peninsula next to South Korea. Due to its location and economic policy support, there are many Korean companies investing in the city. In recent years, driven by the rapid growth of the B2B trade model, surge for orders of material and processing, production and procurement worldwide, multinational companies improve efficiency by the e-commerce platform to optimize supply chain operations, which bring a bunch of shortage of talents who know about Chinese. In addition, the foundation of Confucius Institute overseas provides convenience and a better opportunity for Chinese learners all over the world. Tendency of "Chinese hot" attracts a large number of Korean students to study in China, which makes them to have a better work and prospect in the future.

The statistical visualization analysis report of cross-nation marriages in China civil affairs' statistical yearbook indicates that cross-nation marriages have been on the rise in the past 20 years. As for Beijing, from 2004 to 2010, the number of cross-nation marriages fluctuated around the level of 1000 pairs per year, and the proportion of cross-nation marriages in the total number of marriages changed at about $0.7 \%$. Although the proportion of international marriages in coastal provinces with developed economy is obviously higher than that in other inland provinces, the proportion of international marriages in some central and western provinces has increased more obviously in this process. For example, in Shanxi province from 1998 to 2002, 2003 to 2007, and in Henan province from 2003 to 2007, the ratio of cross-nation marriages in the total number of marriage registrations exceeded $0.2 \%$. In Ningbo, Zhejiang province, for instance, the proportion of female in first cross-nation marriages increased from 2\% in 1999 to $22 \%$ in 2012. Apparently, the continuous expansion of opening to the outside world, the constant enhancement of economic strength and the frequent exchange of foreign science, technology and culture have created favorable conditions for international marriages, and these conditions are obviously more conducive to the establishment of rational, equal and lasting marriage.

Affected by the above factors, international marriage increases, and the number of mixed-blood children has also raised. There are more and more bilingual families in China. Multilingual culture has brought opportunities and challenges to the improvement of bilingual education. Bilingual education-how to make 
children naturally acquire and master two natively language, becomes focus of attention among bilingual families in cross linguistic communities. In addition, owing to the business affairs, preschool children with their parents and come to foreign countries have proliferated. Both groups of children are educated in international schools of a multilingual atmosphere and together form a bilingual community. In essence, the two types of children are slightly different. The former are bilingual children in the natural acquisition environment from born, while the latter are early second language acquisition children in the same language community who receive non-dominant language input in addition to their mother tongue-most of them are in international bilingual schools from kindergarten to high school.

Linguistic environment shapes children's perception of speech sounds, and also children's production of speech sounds [1]. It is often believed that children in bilingual environment can acquire two languages naturally and fluently. In fact, although bilingual children have environment and ability advantages over monolingual children when acquire language, their development situation, personality and psychological differences may lead to the disorder of bilingual system if they are not reasonably interfered and guided. In the long run, it will affect bilingual children's language use preferences. Children may spontaneously rely on the dominant language and gradually lose their second language ability. For these children, bilingual competence is the key to future development. Therefore, how to cultivate children's bilingual development, how to create an effective bilingual environment for children and apply to appropriate learning strategies, are the problems facing training of children's bilingual competence.

\section{Literature Review}

\subsection{Background}

Children active their brain to acquire language naturally since born with cries, in which the innate mechanisms that help them acquire their first language also help them acquire second or subsequent languages in early childhood [2]. Chomsky [3] believes that in the initial state, human brain already exists the Language Acquisition Device or LAD, further to extend is also really a "MAD", or Multilingual Acquisition Device. Bilingual-learning children's more obvious dependence on relatively specific amounts of input from the environment by virtue of the nature of the $\mathrm{LAD}$ (or MAD) and also more practically, for the kind of support parents and other interlocutors provide for language learners. Bruner [4] calls that as LASS, the Language Acquisition Support System.

Children can be categorized into various types of learners at different initial stage of language acquisition and numbers of language they acquire or learn. In terms of language number, children are group into monolingual, bilingual and multilingual child; on the part of language stage of childhood, it can be divided into bilingual first language acquisition, early second language acquisition and late second language acquisition. 
Stages of childhood are often identified according to developmental changes which have been argued to correspond to qualitatively different ways of thinking [5]. These stages also largely follow divisions of schooling: Early childhood (between 2 - 7 years of age, when children are in preschool and the beginning grades); Middle childhood (7 - 11 years, in elementary or middle school); Early adolescence (12 - 14 years, in junior high school); and Later adolescence (15 years and older, in high school) (see, for example, Krause et al., [6]; Muñoz [7]). Besides, there may is a divergence between theorists whether development is seen as a continuous process or characterized by discontinuous stages, as well as whether development takes a unitary course or is dependent on context, e.g., schooling [5]. However, major characteristics of these stages of childhood are well documented, and McKay [8] and Muñoz [7] recommend that these phases can be serve at least as a logical starting point for considering differences between early and older child L2 learners. Gerken [9] provided evidence that there is some ability to do this already established by nine months of age. Howard Nicholas and Patsy M. Lightbown [10] proposed that by age 3, children raised bilingually distinguish not only the languages but also have beliefs about who is expected to speak each language.

\subsection{Bilingual Children and Early Second Language Acquisition Children}

Bilingual first language acquisition refers to the language development of children who can hear two languages at birth. Bilingual acquisition is defined according to a specific language learning environment, which is different from the background of monolingual acquisition. Early second language acquisition refers to monolingual environment in which children can only be exposed to one language at birth, however, due to changes in the language environment of monolingual children, they begin to be regularly exposed to a second language that is different from their mother tongue, usually in children's day care or preschool classes.

De Houwer [11] identifies bilingual acquisition among pre-school children as "the result of the very early, simultaneous, regular and continued exposure to more than one language". Deucher \& Quay [12] proposes that bilingual acquisition is an acquisition phenomenon of exposure to two languages during the first year after birth. Meisel [13] considers that regular exposure to two languages within 3 years after birth is a bilingual acquisition. Given rich enough language interactions in two languages, children can learn them both without explicit, formal instruction. Wang [14] classifies bilingual acquisition from different perspectives. He recommends that according to age, bilingual acquisition can be divided into early bilingual and late bilingual, among which early bilingual can be divided into simultaneous and sequential type with 3-year-old as the boundary; in the light of language acquisition environment, it is divided into natural and learning; on the basis of balance of the two language levels, it can be split into 
balanced and non-balanced bilingual; according to the motivation of second language acquisition, it can fall into self-driven and environment bilingual; based on the characteristics of the formation of cultural identity, it is divided into bicultural and monocultural bilingual.

Peters [15] points that Second language learners (regardless of age) use units such as words, formulae/routines or utterance fragments that can be recognizably traced to the language spoken around them, who do this from their earliest attempts at using the language. While, Howard Nicholas and Patsy M. Lightbow, in the book Second Language Acquisition and the Younger Learner. Child's Play? [16] indicate that "child" second language acquisition is defined as distinct from both "adult" second language acquisition and from either monolingual or simultaneous bilingual development in childhood, which begins at a very early age (certainly before age 3 ) and that there is a gradual development of features that become recognized as "adult second language acquisition" after approximately age 7. And the features that distinguish child from adolescent and adult second language acquisition are variable combinations of phonology, morphosyntax and pragmatics [10].

For a long time, academic community has always been controversial about whether children with early language acquisition have two first languages, or a first language plus a second language. In addition, whether young children acquire two languages at the same time or in succession is suitable for bilingual language acquisition or second language acquisition, and the relationship and difference between the two are still the focus of much discussion.

In the aspects of early language acquisition, B. McLaughlin [17] holds that 3-year-old is the boundary of dividing point. If a child's regular exposure to two languages occurs before the age of three, it is synchronously bilingual acquisition; if the second language input occurs after the age of three, it is acquired sequentially, or it is called bilingual second language acquisition (similar to the notion of early second language acquisition). Even sequentially, the young child learns two languages in the implicit manner characteristic of first language acquisition. An infant bilingual is unambiguously a simultaneous learner, but a child bilingual could be either a simultaneous or sequential learner [18]. The terms for this contrast are Bilingual First Language Acquisition (BFLA) and early Second Language Acquisition (early SLA). So, there is also a difference between learning a language early or late whether the second language is learned "from scratch", independently from the first language, or whether it is filtered through the first language structures. Both infant and child bilinguals are considered early bilinguals as opposed to someone learning a second language late, or after a critical age (yet to be determined). Children learning an L2 within an early sensitive period have a more universal expectation of success, as for other human endowments like walking or binocular vision [19]. Everyone with sufficient exposure including the disabled can achieves native or near-native fluency. By contrast, late second language acquisition is more like a sport, or an ability. 
However, there also be some common characteristics needed to be patient, one thing that monolingual, bilingual, and early second language acquisition have in common is that children acquire language without formal instruction [20]. In sum, Child bilinguals would be the general term for one who can begin both languages at birth simultaneously or learn one first, then after one is established, learn the next one sequentially (or successively), with the caution that the boundary between early and late is porous. So, bilingual and early second language acquisition children all will be passing through the stage of bilingual acquisition.

This article mainly involves two types of children at different stages of language acquisition, one is bilingual children, and the other is early second language acquisition children. Except for family language environment, these children also have discrepancy in initial stage of bilingual acquisition, levels of bilingual ability, and language preferences. Yet, both of them meet the situation of language transfer in the process of acquisition. Orientation of negative and positive transfer is changeable, which indicates it is bidirectional motion without doubt.

\section{Language Transfer}

Transfer is a term of psychology, which refers to the process of applying the previous knowledge and experience to transfer in learning new knowledge. When a previously acquired language (such as a mother tongue) interferes or impedes, promotes or enhances acquisition of a second language, transfer occurs between the two languages. Transfer is widely used in the field of linguistics. Ellis [21] points out that language transfer refers to the phenomenon that learners' existing language (mother tongue) affects the acquisition and development of the second language (foreign language). She also divides transfer into positive transfer and negative transfer. Odlin in Language Transfer states that "transfer refers to the effect of the universality and differences between the target language and any other acquired or not fully acquired language" [22].

There are roughly three factors influencing the language transfer of bilingual children: 1) Cross-lingual characteristics. The universality between different languages serves as the basis for children to learn different languages; ground on universality, different languages have different typological features. For bilingual children, the typological characteristics of two languages they acquire affect the transfer of two language systems, including their closeness and distance in the linguistic feature pedigree, complexity of syntactic rules on the same typological parameters, and the grammatical categories reflected in the syntax of the two languages and so on; 2) Dominant languages. In the bilingual situation, due to language input conditions, in fact, the distinction between dominant and inferior languages generally occurs, and the formation of dominant language is a necessary condition for bilingual children's language transfer. Generally speaking, transfer between languages is from the dominant language to the inferior 
language; 3) The mandatory of syntactic rules. The operating of syntactic rules in language is not always clear and absolute, and there exist many ambiguities of grammatical analysis in language input. However, some studies have shown that the input ambiguity of B language causes the transfer of A language to B language.

For most multicultural families, mother tongue (i.e. the first language in the dominant position of two languages) is always overwhelming, and bilingual development of most children is uneven. At the early childhood, since two languages are still in developmental stage, the dominant mother tongue and the non-dominant second language interact with each other, resulting in bidirectional transfer [23].

\section{Results Analysis}

We have designed practice paper to test the mastery of specific linguistic knowledge of 38 Korean-Chinese children in certain Tianjin Korean international school aiming to collect errors data. There are two types of recipients. One type whose one of parent is Chinese (mostly mother) and the other is Korean; second type of children's parents are both Korean, but these children came to china at birth or shortly after birth who has been acquiring Chinese since at toddlers' stage (approximately 1 - 3 years old). The first group of children are bilinguals, with a total of eight, and the second group are early second language acquisition children, with 30 in total, which age range from 9 to 11 . Early second language acquisition children are different from traditional L2 children. They were enlightened in the Chinese environment at early childhood. Living in the K-C bilingual community, they are naturally affected by the Chinese atmosphere in their daily learning and life. Both types of children show varying degrees of bidirectional transfer in primary school.

There are 38 pieces of test papers collected in total, of which 34 are valid papers (including 8 bilingual children). The test paper is mainly designed for investigating children's bilingual competence, including speech, words, sentence translation and logical comprehension. Purpose of the thesis is to analyze error preference of children involved in the test paper and classify these items. On account of space limitation, speech and syntactic structures with the highest error rates will be analyzed to find out interference factors and causes, and furthermore to give suggestions.

\subsection{Speech}

Error types are as follows:

\begin{tabular}{lll}
\hline & Wrong Pronunciation of Pinyin (BOLD) & $\begin{array}{c}\text { Correct } \\
\text { Pronunciation } \\
\text { of Pinyin }\end{array}$ \\
\hline $\begin{array}{l}\text { Difficulty in Recognition } \\
\text { of Tone Labeling }\end{array}$ & $\begin{array}{l}\text { 姐妹(“sister”) -- jíe mèi } \\
\text { 等候(“waiting”) -- děng hoù/děng hùo }\end{array}$ & $\begin{array}{l}\text { jiě mèi } \\
\text { děng hòu }\end{array}$ \\
\hline
\end{tabular}


Continued

\begin{tabular}{lll}
\hline $\begin{array}{l}\text { Difficulty in Recognition } \\
\text { of Falling-rising Tone }\end{array}$ & $\begin{array}{l}\text { 语法(“grammar”) -- yúpă } \\
\text { 端午节(“Dragon Boat Festival”) - - duān wú jié }\end{array}$ & $\begin{array}{l}\text { yŭ fă } \\
\text { duān wŭ jié }\end{array}$ \\
$\begin{array}{l}\text { Difficulty in Recognition } \\
\text { of Neutral Tone }\end{array}$ & 月亮(“moon”) --yuè liáng & yuè liang \\
$\begin{array}{l}\text { Difficulty in Recognition } \\
\text { of Retroflex Consonant }\end{array}$ & $\begin{array}{l}\text { 栩栩如生(“similar”) -- suí suí/shŭ shŭlú } \\
\text { sheng } \\
\text { 水果(“fruit”) -- suí guŏ }\end{array}$ & $\begin{array}{l}\text { xŭ xŭ rú sheng } \\
\text { shuí guŏ }\end{array}$ \\
\hline
\end{tabular}

This test consists of a total of 30 different tones of Chinese pronunciation. After collection, there following errors are found: 1) Difficulty in recognition of tone labeling. It refers to when a syllable has two vowels, tone symbol is labeled on a quieter vowel rather on a loud vowel, which make it on the wrong vowel. In the test, both of bilingual and early second language acquisition children have experienced different degrees of tone labeling difficulties. Nevertheless, in such situation, correct cases also occurred for both types of children; 2) Difficulty in recognition of falling-rising tone. When "falling-rising + falling-rising" tone site in two-character words, children will be affected by tone sandhi ${ }^{1}$ so that tone of the initial character will have difficulty in identifying its continuous falling-rising tone. In addition, when multi-character words show up multiple tonal patterns, e.g. "duān wŭ jié", recognition of one of its character's falling-rising tone will become relatively difficult; 3 ) Difficulty in recognition of neutral tone ${ }^{2}$. In Chinese, neutral syllables of some words are conventional, so neutral tones must be read at the end of words. In the collection of test data, the accuracy rates of pinyin for the word "yuè liang" (moon) is only 20\%, of which there is one bilingual child and two early language acquisition children; 4) Difficulty in recognition of retroflex consonant. Because of the absence of retroflex consonant in Korean, children cannot effectively distinguish the following three phonemes [s], [tc], [6] (i.e. $/ \mathrm{s} /, / \mathrm{sh} /, / \mathrm{x} /)$.

Chinese is a kind of ideographic characters, while Korean is a phonograms language. Similar to English, Korean vowels and consonants are combined together to form a word, which is different to Chinese "characters" (i.e. "Zì or Cí"). Compositions of Korean are divided into the connatural Korean words, kanji words (Chinese words) and loan words [24]. Loan words include English, Japanese, French and so on. Kanji words account for a large proportion in foreign words of Korean. Therefore, syntactic rules of Korean are similar to Japanese, but there are many words similar to Chinese in pronunciation. Even

\footnotetext{
${ }^{1}$ There are four types of tone in Chinese, which are Yinping (the level tone), Yangping (the rising tone), Shangsheng (the falling-rising tone), Qusheng (the falling tone). In Chinese, when two or more syllables are continuous, the tone of some syllables will change due to the influence of the preceding or subsequent syllable, which is called tone sandhi, such as "guán lì(管理)”, “yáng mă(养 马)"-the first tone change into Yangping, but not for the last tone.

${ }^{2}$ There are four types (1) Yang Ping + neutral tone: such as “chāi shi(差事)”, “yāo jing(妖精)” (2) Yang Ping + neutral tone: such as “nián yue(年月)”, “pán suan(盘算)” (3) Shangsheng + neutral tone: such as “lăo ye(老爷)”, “lăo po(老婆)” (4) Qusheng + neutral tone, such as “yuè liang(月亮)”, "dì fang(地方)".
} 
though there are many similarities in speech, since the large differences between the place and manner of articulation between two languages, similar pronunciation of many vowels and consonants as Pinyin but with different place or manner of articulation result in phonetic confusion. As for consonant, there are 19 in Korean and 22 in Chinese. According to the place of articulation, Korean consonants can be divided into labiodentals, post alveolars, labials, dentals, glottals, Palatals and velars etc. [25]; Chinese has bilabials, dentilabials, apicals, dorsal sounds, dorso-velar sounds. In terms of manner of obstruction of airstream, Korean consonants can be divided into aspirated sounds, Lenis, Fortis, fricatives, flaps, laterals and so on; Chinese has aspirated sounds, unaspirated sounds, stops, fricatives, affricates and laterals. Largely difference as concerned above, for place of articulation, Chinese consonants are special in apicals $(/ \mathrm{z} /, / \mathrm{c} /, / \mathrm{s} /, / \mathrm{d} /$, $/ \mathrm{t} /, / \mathrm{n} /, / \mathrm{l} /, / \mathrm{zh} /, / \mathrm{ch} /, / \mathrm{sh} /, / \mathrm{r} /)$, dorsal sounds $(/ \mathrm{j} /, / \mathrm{q} /, / \mathrm{x} /)$, dorso-velar sounds $(/ \mathrm{g} /, / \mathrm{k} /, / \mathrm{h} /)^{3}$; in terms of obstruction of airstream, Chinese and Korean both have aspirated and unaspirated sound, but unaspirated consonants in Korean are further divided into the opposite of Lenis (/ᄀ/, / ᄂ/, /ᄃ/, /ㄹ/, /ㅁ/, /ㅂ/,

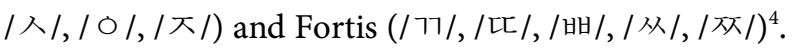

In the test, there show three differences of consonants between Chinese and Korean: 1) The absent of labiodental [f] in Korean, while exist in Chinese. First error type implies that children can't find a corresponding consonant to the Chinese phoneme [f] (/f/) in Korean speech, so children may deem the most similar pronunciation [p'] (/프/) as phoneme [f], which result in a wrong case of pronunciation of "yŭ fã (means "grammar") as "yú pă". 2) The absent of differences between retroflex consonants and blade-alveolar consonants in Korean, while Chinese have discrepancy in which are [ts], [ts'], [s], [z] and [tc], [tch], [c], $[1]^{5}$. This successfully explains the forth error type that the appearance of two allophone errors for phoneme [s] in the word "xŭ xŭ rú shēng". There is no retroflex consonant like [ts], [ts'], [s], [z] in Korean, the most similar pronunciations of consonants may be [tc], [tch], [6], [1]. However, two groups of phonemes are totally different in place of articulation, in Chinese the slightly different in pronunciation caused by place of articulation is more detailed. Therefore, due to the negative transfer of Korean consonant, children may believe that [s] and [s] are in the same phoneme as [6] in Chinese. 3) It causes tone difference on account of the presence or absence of aspirated phoneme in Chinese, while Korean consonants have distinction between Lenis and Fortis in unaspirated sound, which are formed by the looseness of airstream and the tightness of place of articulation. In view of pronunciation, Lenis and Fortis in Korean show pitch per-

\footnotetext{
${ }^{3}$ Apicals $/ \mathrm{z} /, / \mathrm{c} /, / \mathrm{s} /, / \mathrm{d} /, / \mathrm{t} /, / \mathrm{n} /, / \mathrm{l} /, / \mathrm{zh} /, / \mathrm{ch} /, / \mathrm{sh} /, / \mathrm{r} /$ in IPA are transferred as[ts], [t ${ }^{\mathrm{h}]},[\mathrm{s}],[\mathrm{t}],\left[\mathrm{t}^{\mathrm{h}}\right]$, [n], [1], [ts], [ts $\left.{ }^{\mathrm{h}}\right],[\mathrm{s}]$; dorsal sounds $(/ \mathrm{j} /, / \mathrm{q} /, / \mathrm{x} /)$ in IPA are transferred as [tc], [t6 $\left.{ }^{\mathrm{h}}\right],[\mathrm{c}]$; dorso-velar sounds $(/ \mathrm{g} /, / \mathrm{k} /, / \mathrm{h} /)$ in IPA are transferred as $[\mathrm{k}],\left[\mathrm{k}^{\mathrm{h}}\right],[\mathrm{x}]$.

${ }^{4}$ Lenis /ᄀ/, /ㄴ/, /ㄷ/, /ㄹ/, /ㅁ /, /ㅂ/, / ㅅ/, / O/, / ㅈ/ in IPA are transferred as [g], [n], [d], [1], [m],

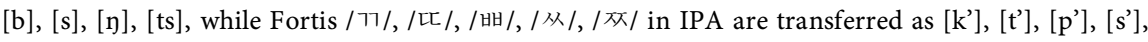
[ts'].

${ }^{5}$ Thses are narrowly translated into IPA form, in norm of pinyin, its broad translation as $/ \mathrm{zh} /, / \mathrm{ch} /$, /sh/, /r/ and /j/, /q/, /x/, /l/.
} 
formance. Bilingual children and early second acquisition children will be affected by lenis in the length of aspiration and tension of place of articulation, when they learn unaspirated consonants of Chinese, so the pronunciation of unaspirated sound may between a Chinese unaspirated sound and Korean lenis, such as /s/ ([s]) and / ᄌ/ ([ts]), in the Chinese word of "sī jī (driver)" (IPA: [s tci]), at a real situation some children pronounced as [ts tci] or [ts t6 ${ }^{\mathrm{h}}$ ].

Furthermore, Chinese is a typical tone language, while Korean is not. There are four types of tone in Chinese: Yinping (the level tone), Yangping (the rising tone), Shangsheng (the falling-rising tone) and Qusheng (the falling tone). For $\mathrm{K}-\mathrm{C}$ children, tone labeling is a major difficulty for them. Among four tones, Yinping and Qusheng are relatively easy for grasp because are similar with contours in Korean, Whereas compared with Yangping and Shangsheng which are confused in contour, children who have difficulty in tone recognition are influenced by lenis of Korean, and show error preference of lower initial pitch in tone of Yinping, Yangping and Shangsheng, not only that, tone sandhi and tone neutralization are also very hard for them to master, such as in the second and third error type of words-“yŭ fă (grammar)", "duān wŭ jié (Dragon Boat Festival)" and "yuè liang (moon)". Therefore, for bilingual children and early second language acquisition children whose dominant language is Korean, they are not sensitive to tone changing in Chinese because of the negative transfer from Korean intonation.

Still, tone labeling difficulty is likely to be affected by two aspects. Korean has more vowels than Chinese, with 11 diphthongs, which are / F/, / 尹/, / $\Perp$ /, / $/$ /, /月/, / 키/, /사/, /내/, / 거/, / 게/ and / ㄱ//6 [24]. While Chinese has 9 diphthongs and 4 triphthongs, which are /ai/, /ei/, /ao/, /ou/, /ia/, /ie/, /ua/, /uo/, /üe/ and /iao/, /iou/, /uai/, /uei/7 respectively. Tone labeling in Chinese is determined according to the sonorant value of vowels, among which the sonorant of [a] is the largest and the sonorant of [y] is the smallest. When two vowels appear in a syllable of pinyin, tone labeling should lay down in the larger vowel. Korean is not a tone language, and more vowels of Korean than Chinese will inevitably affect the judgment of sonorant of vowel. Moreover, bilingual children and early second language children are systematically studying Pinyin in international school, where both Chinese and Korean teacher are in charge of PinYin (Bopomofo) course, so that influenced by their various teaching strategies and methods, these children may be confused and unadaptable to the gap.

$\mathrm{K}-\mathrm{C}$ children are affected not only by Korean speech, but also by Chinese speech. In the code-switching of $\mathrm{K}-\mathrm{C}$ language, in some cases, children may unconsciously output a form of pinyin + Korean, such as "chéng jù 은아무과일이든지다먹는다 (chengjun eats everything)". This is a kind of compensatory strategy. When children can't find the proper and relative phoneme or words of the target language, or it even doesn't exist in one of the lan-

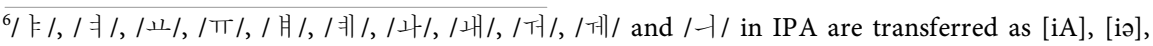
[io], [iu], [ic], [ie], [uA], [uc], [uo], [ue] and [uij].

7/ai/, /ei/, /ao/, /ou/, /ia/, /ie/, /ua/, /uo/, /üe/, /iao/, /iou/, /uai/, /uei/ in IPA are transferred as [ar], [eI], [av], [əu], [iA], [i $\varepsilon$ ], [uA], [uə], [yc], [iav], [iəu], [uar], [ueI.]. 
guages such as some phoneme of special articulation manner, they will adapt avoidance, reduction or compensatory strategy to achieve their goals. In the test, this situation only turns up in the group of bilingual children, and it doesn't show up in the group of early second language acquisition children. This is probably because that, for bilingual children difference of dominant position between Chinese and Korean is relatively small. In order to express their intention to parents and teachers who have different cultural background, bilingual children use Chinese and Korean complementarily and simultaneously for achieving their communicative purpose.

\subsection{Syntactic Structure}

Korean is similar to Chinese in pronunciation and vocabulary. What's more, Chinese and Korean are consistent in the position of modifier and the head, and as accordance as in the relationship between subject and predicate. However, there is a huge divergence in syntactic structure of two languages. Korean is an SOV language, but Chinese is an SVO language that position of verb before object in syntax. The characteristic of Korean is that sentence components expressing secondary meaning put ahead, and predicates expressing primary meaning come behind, which is similar to Japanese [26]. That is a typical feature of SOV structure. In the test, $\mathrm{K}-\mathrm{C}$ children have also encountered this kind of syntactic error. We selected several representative answers from two test sentences as following:

I) Korean to Chinese
1) (어떤) 학생 하나가 교실에 앉아있다. (there is) student one classroom sitting
[Right answer: xué shēng zài jiāo shì lĭ zuò zhe]
Children's Answer:
a) yŏu yī wèi tóng xué zài jiāo shì lŭ zuò (there is one student in the classroom sitting)
b) yī gè xué shēng zài jiāo shì lĭ zuò (one student in the classroom sitting)
c) yŏu yī gè xué shēng zài jiāo shì lî zuò zhe yĭ zi (there is one student in the classroom sitting chair)
d) yĩ gè xué shēng zuò zài jiāo shì lĭ (one student sit in the classroom)
e) xué shēng zuò zài jiāo shì lì (student sit in the classroom)
f) xué shēng yī gè zuò bān lì (student one sit in the classroom)
2) 이번 주말 농구하고 영화 보는 거 외에도 나는 친구들과 같이 등산을 갔다.
(this weekend basketball film watch except also I friends together climb went) 
[Right answer: zhè zhōumò chúle dă lánqiú kàn diày̆ng, wŏ hái hé péngyŏu yīqŭ qù páshānle]

Children's Answer:

a) chúle zhèzhōu wán lánqiú hé kàn diànyinng yǐwài, wǒ háigēn péngyŏu men dēngshān le

(except this weekend play basketball and watch film [except],

I also with friends climb [past])

b) chúle zhè zhōumò wán lánqiú kàn diàny̌̌ng, háigēn wŏde péngyŏu dēngshān

(except this weekend play basketball watch film, also with my friends climb)

c) zhègè zhōumò chúle dă lánqiú kàn diàyı̌ng, háiyŏu

gēn péngyŏu qùle dēngshān

(this weekend except play basketball watch film, also

with friends went climb)

d) zhègè zhōumò chúle dă lánqiú kàn diàny̆ng, háiyŏu gēn péngyŏu qù dēngshān le

(this weekend except play basketball watch film, also with friends went climb [past])

e) zhècì zhōumò chúle lánqiú hé kàn diàny̆nng hái wŏ gēn péngyŏu yīqu dēngshān le

(this weekend except basketball and watch film also I with friends together climb [past])

f) zhègè zhōumò chúle kàn diànyinng, hái qù páshān gēn wŏde péngyŏu

(this weekend except watch film, also went climb with my friends)

There is no morphological change in Chinese, and grammatical meaning is based on word order and function words. So, Chinese characters are ideographic, combining sound and meaning. In Korean, according to certain morphological rules, "active" morphemes are attached to the stem, and therefore, free morph and word order of words are used to express syntactic features. Chinese is a SOV language, so predicate is in the middle of the sentence, before the object. Chinese without morphological changes can't achieve a free word order like Korean. If the predicate is placed at the end of a sentence, the meaning of the sentence will be confused. Amid many syntactic differences, the biggest one between Korean and Chinese is reflected in the sentence position of predicate and object. The Korean predicate is sited at the end of the sentence. For example, In (1) the verb "sitting(앉아있)" is at the end of the sentence in Korean, but it should be located before the object in Chinese. In (2) "except... for (외에)" is a preposition phrase, which refers to the phrase formed by a preposition attached to a head word. Prepositions are one of the unique parts of speech in Chinese. Yet, there are no prepositions or preposition phrases in Korean. Not only that, adverbials of time in Chinese usually appear at the beginning of a sentence or at 
the beginning of a clause.

In (1) both bilingual and early second language acquisition children are affected by the negative transfer of Korean. In the test sentence, "앉아있(sitting)" ground at the end of the sentence, after the object "교실(classroom)", so the answer for translating into Chinese, the verb "坐着(sitting)" should be located in front of the object "jiāo shì (classroom)". The answer of (1a) and (1b) made by children, which are not conventional usage in Chinese, is probably interfered by the negative transfer of "verb behind" in Korean syntax. It is worth noting that although negative transfer occurred, some children still successfully overcame it, accounting for $53 \%$. Not only does that happen to bilingual children, but also to early second language acquisition children. In (2), as for no preposition in Korean, so Korean children, even they are early second language acquisition children, still can't find the parameters of rules of proposition phrase in their brain domain. In the sentential order of (2), the word "외에 (except ...for)" appears after the verb "보는(watch)", which expresses a total exclusion of the aforementioned fact. The adverb of time is seated at the beginning of the sentence included in aforementioned facts. Therefore, the Chinese answer of sentence (2) arise that children put the adverb of time "zhègè zhōumò (this weekend)" after proposition phrase "chú le... (except ...for)". Although the logical form of sentences in two languages is consistent in children's brain, words sequence of the surface structure is affected by Korean syntactic rules. In addition, it also found that the proposition phrase "gēn wŏde péngyŏu (with my friends)" is situated at the end of sentence opposite to the syntactic structure of Chinese, such as (2f).

In fact, under two linguistic environments, in the process of language output, children will inevitable carry out recognition-decoding-conversion for the language they receive, and use target language to feedback. However, syntactic structure of Korean and Chinese is so different that outputs of the test children is not suitable for Chinese conventional grammar, influenced by negative transfer of Korean. Meanwhile, those children who successfully overcome negative transfer do not mean that they have overcome negative transfer from and received positive transfer of Chinese. In the $\mathrm{K}-\mathrm{C}$ test, phenomenon of negative transfer from Chinese also appeared:

II) Chinese to Korean

mǐnzhū kàndào wǒ ná zhezì jǐ́dezhàopiàn

3) 敏珠着到 我拿着自己的照片

[Right answer: 민주는 내가 자기의 사진을 가지고 있는 것을 봤다]

Minzhu I my photo holding (aspect) saw

Children's Answer:

a) 민주 봤다 내가 가젔던 사진을

Minzhu saw I holding photo

In (3a), the verb “봤다(see)" is in the middle of the sentence and behind the object "봤다(I)", which violates the syntactic rule of SVO in Korean. This case is picked up from children whose dominant language is Chinese. Still, this kind of children also makes errors as example (2a-b). Among which, a six-grade student 
offer an answer to the first test sentence is (1f)— “xué shēng yī gè zuò bān lî". Apparently, he accepted both of transfer from Korean and Chinese, simultaneously and come about bi-disorder of syntactic rules.

From answers in example (1) to (3), two types of condition happen when children affected by language transfer (i) object-predicate inversion (ii) shift of topic focus in prepositional objective phrase.

\subsubsection{Object-Predicate Inversion}

Errors of word order show up in all three test sentences, and bilingual children and early second language acquisition children influenced by Korean produce "predicate behind" in Chinese translation, besides, in the same test paper, Korean translation is also affected from Chinese transfer. There are three sorts of situation came out in translation question: 1) Bidirectional linguistic error. There are few children who made errors simultaneously in test sentence (1) and (3), like (1a-b) and (3a), only two of them are both early second language children. It is considered that this condition is because that chaos of word order caused by synchronous negative bidirectional transfer, so children may unconsciously use the relative syntax structure to answer the question of present language. But this situation only limits in the range of test paper, while they can fluently communicate with their parents in daily life. In virtue of low competence and poor communication skills in Chinese, these children lack confidence of speaking Chinese, so except for class, they are more inclined to use Korean to talk with others or express their minds. 2) Unidirectional linguistic error. This mainly occurs in group of bilingual children, who are originally in two native language environments, yet under the impact of language status in families shows difference. In Chinese-Korean family, where Chinese is in the dominate position, children are encouraged to speak more Chinese than Korean which implies children largely affect by Chinese language transfer, while in Korean-Chinese family, children are more likely accepting language transfer from Korean. 3) Complementary error. This type is found in both bilingual and early second language acquisition children. In the Korean international school, children are class into four levels of class, $\mathrm{A}$ to $\mathrm{D}$, children with complementary error are from class $\mathrm{A}$ and class B. These children are lively and cheerful, positive to learn Chinese and love communication. They constitute a Chinese leading speech community and a Korean leading speech community in the class, while Korean is selected as a common speech in communication between two groups which is because the teaching model in the international school is based on the standard issued by the Ministry of education of South Korea. What's more, except for Chinese lesson, other courses are taught by Korean teachers. In Chinese course, in order to complete classroom task, children would make complementary errors, such as types of "Chinese plus Korean" and "Korean plus Chinese" in example (3a), to achieve communicative purposes.

\subsubsection{Shift of Topic Focus in Prepositional Objective Phrase}

In example (2), aside from the occurrence of object-predicate inversion, there is 
also a shift of topic focus in prepositional objective phrase. Chinese is a topic-prominent (TP) language, that the basic structure of sentences favors a description in which the grammatical relation topic-comment plays a major role [27]. In TP language, topic is inconsistent with subject, and besides topicalization is higher than the degree of subject grammaticalization. Topic in Chinese isn't generating from displacement but embedded in the basic syntactic structure, which topic focus is influenced by pitch, duration, sound intensity, phrase structure and other factors, shifting at the original position. Korean is a subject prominence and topic prominence language [27], which means that there are two equally important distinct sentence constructions, the subject-predicate construction and the topic-comment construction. Topicalization in Korean accompany with grammaticalization of subject, that is, focus on topic is as concerned as it on subject. Topic can directly attach to subject, located in the sentence-initial with markers, yet topic disagree with predicate, because topic is not determined by the verb, topic selection is independent of verb. As far as syntactic structure concerned, in example (2), "외에 (except ... for)" in Korean expression is placed after the verb "보는(watch)", not only that, the time adverb before the verb is also excluded, so subject and topics are both prominent and focused. From the point of semantic meaning, topic of prepositional phrase "chú le... (except)" in Chinese gather on "dă lánqiú, kàn diànyı̌ng (play basketball and watch movies)", which excludes adverbials of time. Therefore, children replied answers as (2a) and (2b) in question of Chinese translation, topic focus is extended to adverbials of time, shifting on phrase "zhè zhōumò (this week)". It is worth noting that we have also collected data of answers like (2c)-(2d) correctly corresponding to the topic focus sentence of Chinese. This indicates that in the process of code-switching, children receive impact simultaneously from markers of subject and topic in Korean and change topic focus, so shift of topic focus in prepositional objective phrase arises in translation, and semantic logic is also affected.

When children judge word order in sentences, they will be influenced by syntactic structure from two languages. Not only do they make predicate inversion among Chinese and Korean, but also shift topic focus in different languages, which indicates that syntactic transfer on children is bidirectional with no explicit sequential orders but affected by transfer distance between languages.

\section{Discussion}

\subsection{Bidirectional Transfer}

Development of language is a dynamic process. The external ecological environment for children to acquire two languages may also change to a certain extent, and dominant language and non-dominant language can convert under certain conditions. From the perspective of speech and syntax, K-C children's bilingual decoding is not a one-way process, but a bidirectional and dynamic process [28]. Positive and negative transfer of two languages may switch that 
leads to disorder of acquiring grammatical rules. Since language advantage result in asymmetry of transfer, which makes the phenomenon of conversion of positive and negative transfer between bilingual or multi-language is relatively weak and easy to be ignored. In Pearson \& Fernandez's bilingual-learning infants' study [29], there occurred a special case that a little girl begun both languages at birth, however, she seemed to be filtering the second language through the first, like a second-language learner. That's maybe cause of diversity of the alternating occurrence frequency between two languages or the different status of them. In the study, based on the difference of dominant languages, both bilingual and early second language acquisition children exhibit different degrees of bidirectional transfer in the process of bilingual education. In addition, at the early stage of bilingual acquisition, influenced by bidirectional transfer, children may be unconformable for their inadequate vocabulary, poor understanding of grammar and fuzzy logic, which yields difficulty in communication and negative emotion [30] towards the use of bilingualism.

Although each bilingual child has different language growth environment, cultural background and development situation, the process of language acquisition they have experienced is almost the same or similar. In the time of bilingual acquisition, if the development of one language is ahead of the other, the dominant language features will filter into non-dominant language. However, the interaction between the two languages is not unidirectional, some linguistic features of non-dominant language also affect the dominant language. We simulate a following dynamic schema of bidirectional transfer:

\section{[Transfer Distance] \\ Dominant transfer $\Longrightarrow$ Non-dominant transfer}

Greater of transfer distance between dominant language and non-dominant language, language would be less affected by transfer, and the language model is more stable. On the contrary, smaller of transfer distance, the language model would be unstable, resulting in language disorder. Secondly, transfer distance is also influenced by the degree of similarity between two languages. The larger the language similarity is, the greater the transfer distance would be, while the smaller the language similarity is, and the smaller the transfer distance would be.

\subsection{Teaching Strategies and Suggestions}

By means of contrastive and errors analysis of speech and syntactic structure of K-C children, the following suggestions are made: 1) Pay attention to the systematic teaching of speech and grammatical rules. In terms of speech, in light of explanation and demonstration to help children distinguish place and manner of articulation in Korean-Chinese and master pronunciation skills. Syntactically, teachers have to clarify differences of syntactic structure between two languages, strengthen and distinguish difficult points in Korean and Chinese. In addition to 
explaining phonetic features and syntactical rules, it is necessary to divide and summarize linguistic knowledge for children. 2) Realize the interaction between acquisition and learning, and focus on children's psychological changes in the use of bilingualism. Because of the difference in the speed of receiving bilingual signals and influence of psychological factors, it is bound to lead to the imbalance or even disorder of bilingual development. Therefore, it is necessary to clarify the guiding role of systematic education, reduce the burden of children's language acquisition, and encourage them to use more bilingual dialogue. 3) Attach importance to the role of bidirectional transfer, and guide children to correctly understand it. Strengthen educational interventions, use contrastive approach to analyze language differences, predict difficulties and errors that will be encountered in bilingual systematic education, and use prediction to deal with certain items of bidirectional transfer in a specific way. Through intensive training, to help children overcome interferences caused by bidirectional transfer and establish a mutual independent language thinking pattern.

\section{Conclusions}

It is worth noting that in second language acquisition, we have frequently focused on the interference of language transfer from the mother tongue to the acquisition of the target language, or the interaction of language transfer between dominant and non-dominant languages in bilingual acquisition. Under the cover of the influence of negative transfer, the positive transfer is often ignored, which makes people think that the language transfer is a one-way development, or one occurs after the other. However, K-C children show a bidirectional and dynamic change in the process of bilingual acquisition, just like the direction of alternating current changing back and forth. So, the truth is that positive and negative transfer will be transformed in the interaction process, which is obviously a dynamic interaction process, rather than a one-way-change other.

Bilingual acquisition is a constantly changing development process. Bidirectional transfer in Korean and Chinese is a normal language phenomenon, and it is also an unavoidable way for bilingual children and early second language acquisition children. Although children's brains are inherently capable of revising linguistic rules, if they are not properly guided and reasonably intervened, it will lead to a chaos of bilingual system. At present, the number of bilingual children is constantly increasing, so systematic bilingual education and ground of bilingual communities are particularly important. Bilingual and second language competence can help to stimulate children's cognitive ability and exercise abstract thinking in some sense. In spite of universal grammar holds that children are born with language mechanisms and ability to adjust language parameters, but the acquired environments and use of learning strategies play an important role in correcting children's language errors. Due to space limitations, this paper didn't further analyze the vocabulary and logic understanding part of the test, 
but still finds some problems faced by bilingual and early second language acquisition children in language acquisition. We believe that creating an ideal language environment for children, ensuring that they get "understandable input" as much as possible, and to get a systematic bilingual education, children's bilingual competence can reach a relatively complete level before adolescence.

\section{Acknowledgements}

I am very grateful to my supervisor Prof. Daoshan Ma for his patient guidance, valuable suggestions and constant encouragement and comments, which have prompted many useful revisions to this paper. Thanks also to Open Access Library Journal for giving me the opportunity to clarify many of my thoughts to the world.

\section{Conflicts of Interest}

The author declares no conflicts of interest regarding the publication of this paper.

\section{References}

[1] Ma, D.S. (2018) An Introduction to Linguistics. Shantou University Press, Shantou.

[2] Shao, Z.Y. (2019) Language Evolution in Biolinguistics from a Multi-Factor Perspective. Open Access Library Journal, 6, 1-17. https://doi.org/10.4236/oalib.1105867

[3] Chomsky, N. (1965) Aspects of the Theory of Syntax. MIT Press, Cambridge. https://doi.org/10.21236/AD0616323

[4] Bruner, J. (1983) Child's Talk: Learning to Use Language. Norton, New York.

[5] Berk, L.E. (2006) Child Development. 7th Edition, Pearson Education, Boston.

[6] Krause, K.D., Bochner, S. and Duchesne, S. (2003) Educational Psychology for Learning and Teaching. Thompson, Southbank.

[7] Muñoz, C. (2007) Age-Related Differences and Second Language Learning Practice. In: DeKeyser, R., Eds., Practice in a Second Language: Perspectives from Applied Linguistics and Cognitive Psychology, Cambridge University Press, Cambridge, 229-255. https://doi.org/10.1017/CBO9780511667275.014

[8] McKay, P. (2006) Assessing Young Language Learners. CUP, Cambridge. https://doi.org/10.1017/CBO9780511733093

[9] Gerken, L. (2004) Nine-Month-Olds Extract Structural Principles Required for Natural Language. Cognition, 93, B89-B96. https://doi.org/10.1016/j.cognition.2003.11.005

[10] Nicholas, N. and Lightbown, P.M. (2008) Defining Child Second Language Acquisition, Defining Roles for L2 Instruction. In: Philp, J., Oliver, R. and Mackey, A., Eds., Second Language Acquisition and the Younger Learner. Childs Play, John Benjamins Publishing, Amsterdam, 27-51. https://doi.org/10.1075/1llt.23.04nic

[11] De Houwer, A. (1995) Bilingual Language Acquisition. In: Fletcher, P. and MacWhinney, B., Eds., The Handbook of Child Language, Blackwell, Oxford, 219-250. https://doi.org/10.1111/b.9780631203124.1996.00009.x

[12] Deuchar, M. and Quay, S. (2001) Bilingual Acquisition: Theoretical Implications of a Case Study. Oxford University Press on Demand, Oxford. 
[13] Meisel, J.M. (2001) From Bilingual Language Acquisition to Theories of Diachronic Change. Sonderforschungsbereich 538, Hamburg.

[14] Wang, W.Y. (2010) Development of Bilingual Children's Competence: An Empirical Review. Foreign Languages Research, 3, 54-62.

[15] Peters, A. (1983) The Units of Language Acquisition. CUP, Cambridge.

[16] Philp, J., Oliver, R. and Mackey, A. (2008) Second Language Acquisition and the Younger Learner: Child's Play? John Benjamins Publishing, Amsterdam. https://doi.org/10.1075/1llt.23

[17] McLaughlin, B. (1978) Second Language Acquisition in Childhood. Lawrence Erlbaum Associates, Hillsdale.

[18] Bavin, E.L. and Naigles, L.R. (2009) The Cambridge Handbook of Child Language. Cambridge University Press, Cambridge. https://doi.org/10.1017/CBO9780511576164

[19] Hyltenstam, K. and Abrahamsson, N. (2000) Who Can Become Native-Like in a Second Language? All, Some, or None? Studia Linguistica, 54, 150-166. https://doi.org/10.1111/1467-9582.00056

[20] Zhang, S. (2016) El bilingüismo como primera lengua: Teorías, métodos y análisis. Editorial Académica Española, Publicia.

[21] Ellis, R. (1999) Understanding Second Language Acquisition. Shanghai Foreign Language Education Press, Shanghai.

[22] Odlin, T. (1989) Language Transfer: Cross-Linguistic Influence in Language Learning. Cambridge University Press, Cambridge. https://doi.org/10.1017/CBO9781139524537

[23] Pavlenko, A. (2000) New Approaches to Concepts in Bilingual Memory. Bilingualism: Language and Cognition, 3, 1-4. https://doi.org/10.1017/S1366728900000110

[24] Bao, Z.D. (2009) A Comparative Study of Chinese Learning among Chinese Ethnic Koreans and Rok Koreans. Tianjin Normal University, Tianjin.

[25] Li, J.Y. (2019) Comparison of Korean and Chinese Phonetics and Strategies for Korean Speech Study. Think Tank Era, 43, 123.

[26] Ru, Y. (2014) A Comparative Study of Word Order between Korean and Chinese. Research on Foreign Language Education and Translation Development, 3, 269-271.

[27] Li, C.N. and Thompson, S.A. (1976) Subject and Topic: A New Typology of Language. In: Li, C.N., Ed., Subject and Topic, Academic Press, New York, 457-489.

[28] XI, D. (2014) A Study of Bilingual Transfer in Bilingual Acquisition of Children under Chinese Environment from Wh Displacement. Read and Write Periodical, 11, 15-16.

[29] Pearson, B.Z. and Fernandez, S.C. (1994) Patterns of Interaction in the Lexical Development in Two Languages of Bilingual Infants and Toddlers. Language Learning, 44, 617-653. https://doi.org/10.1111/j.1467-1770.1994.tb00633.x

[30] Liu, L.X. (2013) The Bilingualism Study of a Pair of Twins between Chinese and Korean. Shandong University, Jinan. 